\title{
Model of extensive and severe tracheal stenosis in $\operatorname{dog} s^{1}$
}

\author{
Modelo de estenose traqueal extensa e grave em cães
}

\author{
Jairo Vaidergorn', Djalma José Fagundes", Ana Lucia Machado"II, Rimarcs Gomes Ferreira ${ }^{\text {IV }}$, Yara Juliano ${ }^{\mathrm{V}}$, Neil Ferreira \\ Novov", Paulo de Oliveira Gomes ${ }^{\mathrm{VI}}$ \\ ${ }^{I} \mathrm{PhD}$, Associate Professor, Cardio-Thoracic Surgery Division, Medicine School of Santo Amaro University (UNISA), Sao Paulo, Brazil. \\ ${ }^{\text {II }} \mathrm{PhD}$, Associate Professor, Operative Technique and Experimental Surgery Division, Department of Surgery, Federal University of Sao Paulo \\ (UNIFESP), Brazil.

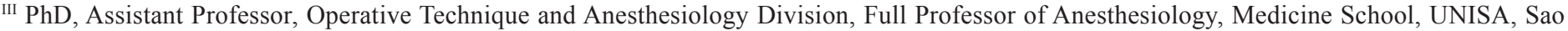 \\ Paulo, Brazil. \\ IV Full Professor, Pathological Anatomy Division, Medicine School, UNISA, Sao Paulo, Brazil. \\ ${ }^{v}$ PhD, Full Professor of Public Health, Medicine School, UNISA, Sao Paulo, Brazil. \\ vi PhD, Associate Professor, Department of Surgery, UNIFESP, Sao Paulo, Brazil.
}

\begin{abstract}
Purpose: To create an animal model of extensive longitudinal tracheal stenosis (TS) that can be useful to test different surgical techniques of tracheal reconstruction. Methods: Twenty male mongrel dogs were submitted to standard TS and randomly distributed to observation for 3 weeks $(n=10)$ or 6 weeks $(n=10)$. Under general anesthesia, an elliptical area (major axis from $1^{\text {st }}$ to $20^{\text {th }}$ ring and minor axis $40 \%$ of tracheal diameter) was resected and the stumps were sutured. The internal and external diameters were measured (before and after the observation time) and the stenosis index was calculated. Blood samples were collected (gasometry, hematocrit and hemoglobin.) before and after the surgical proceedings. Results: The weight was significant lower in the animals of 6 weeks $(15,551 \pm 3286.2)$ in comparison with those of 3 weeks observation $(17,250 \pm 3575.0)$. No significant differences were noted in the extension of the trachea on the $21^{\text {st }}$ day $(21.2 \pm 1.8)$ or $42^{\text {nd }}$ day $(21.1 \pm 1.7)$. The mean (40.1) and the median (40.5) of rings counted on the $21^{\text {st }}$ day were quite similar to mean (38.1) and median (39.0) that were counted on the $42^{\text {nd }}$ day. In the animals of group A (3 weeks) the mean (46.8\%) and the median (49.8\%) of index stenosis showed no significant difference (Mann Whitney test $\mathrm{p}<0.001)$ in comparison with the mean $(55.1 \%)$ and median $(52.4 \%)$ of the animals from group B (6 weeks). No mechanical or biochemical distresses were recorded through all period of observation. Conclusion: The surgical proceeding was effective to promote a model of longitudinal and extensive tracheal stenosis.
\end{abstract}

Key words: Tracheal Stenosis. Models, Animal. Dogs.

\section{RESUMO}

Objetivo: Criar um modelo de estenose longitudinal extensa que possa ser útil para testar diferentes técnicas operatórias de reconstrução traqueal. Métodos: 20 cães sem raça definida foram submetidos a um procedimento padrão de estenose traqueal extensa e observados por três $(n=10)$ ou seis $(n=10)$ semanas. Sob anestesia geral uma área elíptica (eixo maior do $1^{\circ}$ ao $20^{\circ}$ anel traqueal e eixo menos com $40 \%$ do diâmetro da luz traqueal) foi ressecada e os cotos foram anastomosados de modo término-terminal. O diâmetro interno e externo foi medido (antes e depois do período de observação) e o índice de estenose foi determinado. Amostras de sangue foram coletadas (gasometria, hematócrito e hemoglobina) antes e depois dos procedimentos operatórios. Resultados: O peso foi significantemente menor nos animais de seis semanas $(15,551 \pm 3286.2)$ em comparação com os de três

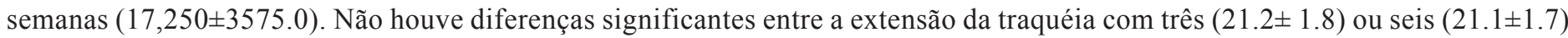
semanas. A média (40.1) e a mediana (40.5) dos anéis contados na $3^{\mathrm{a}}$ semana foi similar à média (38.1) e mediana (39.0 da $6^{a}$ semana. A média $(46.8 \%)$ e mediana $(49.8 \%)$ do índice de estenose com três semanas não mostrou diferenças significantes (Mann Whitney test $\mathrm{p}<0.001$ ) com a média 55.1\%) e mediana de seis semanas $(52.4 \%)$. Nenhum sofrimento mecânico ou bioquímico da respiração foi assinalado. Conclusão: O procedimento foi efetivo para promover um modelo de estenose extensa da traquéia. Descritores: Estenose Traqueal. Modelos Animais. Cães.

${ }^{1}$ Research performed at Surgery and Experimentation Post-Graduate Program, Operative Technique and Experimental Surgery Division, Department of Surgery, Federal University of Sao Paulo (UNIFESP), and Cardio-Thoracic Surgery Division, Medicine School of Santo Amaro University (UNISA), Brazil. 


\section{Introduction}

Congenital diseases, ${ }^{1}$ trauma, ${ }^{2,3}$ tumors,${ }^{3}$ long time tracheal intubation ${ }^{4}$ or other surgical proceedings can promote several degrees of tracheal stenosis (TS) associated to the severity, extension or duration of injury. The healing fibrous tissue causes tracheal patency impairment and mechanical distress on the ventilatory physiology; sometimes surgery would be the only available treatment option.

Primary resection and end-to-end repair with a slide technique should always be the first option..$^{4-7}$ However, in cases of extensive longitudinal stenosis a tracheotomy below to the stricture area could be necessary and the stenosis treated with orthesis, repeated mechanical dilations, ${ }^{4}$ implant of biological ${ }^{8}$ or synthetic tissues ${ }^{9}$, prosthesis, ${ }^{10-13}$ or recently with the use of homologues or heterologues tracheal transplantation. ${ }^{14-16}$

The surgical treatment for extensive stenosis of trachea is not a consensus amongst numerous and controversial surgical proceedings. The purpose of this research is to create an animal model of extensive longitudinal TS that should be useful to test different surgical techniques of tracheal reconstruction.

\section{Methods}

The experimental protocol (1431/03) was approved by the Ethics Committee of the Federal University of São Paulo - Escola Paulista de Medicina (UNIFESP - EPM). All the procedures followed strictly the existing regulations about animal experimentation (Brazilian College on Animal Experimentation - COBEA).

Twenty male mongrel dogs, with an average weight of $17 \mathrm{~kg}$, all under sanitary care of the Veterinarian Division of Santo Amaro University, were randomly distributed into two groups. Group A ( $\mathrm{n}=10)$ : induction of TS and 3 weeks of observation and Group B: induction of TS and 6 weeks of observation.

All the surgical procedures and euthanasia were performed under general anesthesia, using an intramuscular dose $\left(25 \mathrm{mg} . \mathrm{Kg}^{-1}\right)$, of ketamine (Ketalar ${ }^{\mathrm{TM}}$ - Medical Divison of Pfizer do Brazil - São Paulo - Brazil) an intravenous dose $\left(5 \mathrm{mg} \cdot \mathrm{Kg}^{-1}\right)$ of Propofol (Diprivan ${ }^{\mathrm{TM}}$ - AstraZeneca do Brazil - Sao Paulo - Brazil) and an intravenous infusion of saline solution of sodium chloride $0,9 \%\left(30 \mathrm{ml} \mathrm{Kg}^{-1}\right.$ in one hour). Pulmonary ventilation after oro-tracheal intubation was stated by Mapleson - D system with oxygen flow of $70 \mathrm{ml} \mathrm{Kg}^{-1}$.

Under aseptic conditions a median and longitudinal cervical incision $(15 \mathrm{~cm})$ allowed access from the first until to the $20^{\text {th }}$ tracheal ring. Using a pachymeter the external diameter of trachea was measured in the antero-posterior and latero-lateral directions. The measure of distance between the first and $20^{\text {th }}$ ring was taken as a major ratio of an elliptical area of resection. The minor ratio was calculated by $40 \%$ of the latero-lateral diameter of the trachea. A transversal incision in the $10^{\text {th }}$ ring allowed the measuring of the internal diameter of the trachea in both antero-posterior and latero-lateral directions. In the anterior face of the transversal tracheal incision, about $40 \%$ of external diameter was taken as a baseline of two triangles: the cranial triangle with the apex in the first ring and the caudal triangle with the apex in the $20^{\text {th }}$ ring. The two triangles determined the extension of standard area for tracheal resection.
A single row of continuous polypropylene 4.0 suture closed the longitudinal cranial and caudal incisions and another circular single row of continuous polypropylene 4.0 sutured the two stumps and closed the tracheal lumen. The resection and the posterior tracheal reconstruction promoted a standard segment of tracheal stricture. After one hour of the incision suture and anesthesia recovery a blood sample was collected to determine the values of arterial gasometry, hematocrit and hemoglobin.

During the first 48 hours of post-operative time the analgesia was done with intramuscular promazine hydrochloride $(2 \mathrm{ml})$ and dipirone $(2 \mathrm{ml})$ twice a day. A single dose of benzyl penicillin-procaine $\left(500,000 \mathrm{UI} . \mathrm{Kg}^{-1}\right)$ was administrated immediately after the anesthesia induction.

During the observation period it was recorded the occurrence of respiratory distress, sub-cutaneous emphysema, tongue or lips cyanosis, fever, incision infection or abscess, dysphagia, liquid stools or refuse of the chow or drinking water. Once any sign of severe suffering was identified, the Veterinarian interrupted the research and the animals were euthanatized.

On the $21^{\text {st }}$ or $42^{\text {nd }}$ day under anesthesia euthanasia was performed by intravenous injection of potassium chloride until cardiac arrest, before the collection of blood sample (arterial gasometry, hematocrit and hemoglobin). The entire extension of trachea was measured from the first to the $20^{\text {th }}$ ring and the number of rings was counted. The external and internal diameter of the $10^{\text {th }}$ ring were measured with pachymeter in both anteroposterior and latero-lateral directions. The trachea was transversally cut and resected just above of the cricoid cartilage (point A) and just above of the $20^{\text {th }}$ ring (point B). The internal diameters of both points (A and $\mathrm{B}$ ) were carefully measured. The internal diameter was also measured in the $10^{\text {th }}$ ring (point $\mathrm{C}$ ).

The significance of the differences of weight (grams) and tracheal diameters $(\mathrm{cm})$ were evaluated by " $\mathrm{t}$ " test and Wilcoxon test $(\mathrm{p}<0.05)$. The $\mathrm{pH}$ and base excess values were evaluated by Mann-Whitney and Wilcoxon tests $(\mathrm{p}<0.005)$. The significance of the differences in the $\Delta \%$ scores of diameter measurements were evaluated by " $t$ " test or Mann Whitney test and $p$ value $<0.05$ was considered to be statistically significant.

\section{Results}

The weight (grams) of animals from group A (3 weeks) on the first day $(17,903 \pm 3766.5)$ showed no significant difference in comparison to the $21^{\text {st }}$ day $(17,250 \pm 3575.0)$. On the other hand, in the group B (6 weeks) the initial weight $(17,220 \pm 3774.4)$ was significantly higher than on the $42^{\text {nd }}$ day $(15,551 \pm 3286.2)$.

The mean (Wilcoxon test $\mathrm{p}<0.001$ ) of $\mathrm{pH}$ measured on the first day $(\mathrm{pH}=7.4)$ and on the $21^{\text {st }}$ day $(\mathrm{ph}=7.3)$ in the animals of Group A ( 3 weeks) showed no statistical difference $(\Delta \%=-0.9)$. The same occurred with the animals on the group B (6 weeks) in the first day $(\mathrm{pH}=7.3)$ and $42^{\text {nd }}$ day $(\mathrm{pH}=7.3)$.

The mean (Wilcoxon test $\mathrm{p}<0.001$ ) of base excess measured on the first day $(B E=-4.9)$ and on the $21^{\text {st }}$ day $(\mathrm{ph}=-7.4)$ in the animals of Group A (3 weeks) showed no statistical difference $(\Delta \%=-7.4)$. On the other hand, the animals in the group $B$ ( 6 weeks) on the first day $(\mathrm{BE}=-8.7)$ and $42^{\text {nd }}$ day $(\mathrm{pH}=-4.4)$ showed a significantly difference $\left(\Delta \%=-364.7^{*}\right)$. 
The mean (40.1) and the median (40.5) of rings counted on the $21^{\text {st }}$ day were quite similar to mean (38.1) and median (39.0) that were counted on the $42^{\text {nd }}$ day (Mann Whitney test $p<0.001$ ).

No significant differences were noted ("t" test $\mathrm{p}<0.001$ ) on the total extension $(\mathrm{cm})$ of the trachea on the $21^{\text {st }}(21.2 \pm 1.8)$ or $42^{\text {nd }}$ day $(21.1 \pm 1.7)$. The mean $(46.8 \%)$ and median $(49.8 \%)$ of tracheal stricture extension $(\mathrm{cm})$ on the $21^{\text {st }}$ day were similar to the mean $(50.1 \%)$ and median $(52.4 \%)$ on the $42^{\text {nd }}$ day (" $t$ " test $\mathrm{p}<0.001)$.

The mean and standard deviation $(\mathrm{cm})$ values of external diameter at point $\mathrm{C}$ (stenosis middle area) from animals of group $\mathrm{A}$ ( 3 weeks) on the $1^{\text {st }}$ day $(1.9 \pm 0.3)$ was significantly larger than on the $42^{\text {nd }}$ day $(1.3 \pm 0.2)$. The Wilcoxon test $(\mathrm{p}<0.001)$ showed a $(\Delta \%=-29.9 *)$.

The mean and standard deviation $(\mathrm{cm})$ values of external diameter at point $\mathrm{C}$ (stenosis middle area) from animals of group $\mathrm{B}$ (3 weeks) on the $1^{\text {st }}$ day $(1.9 \pm 0.2)$ was significantly larger than on the $42^{\text {nd }}$ day $(1.3 \pm 0.3)$. The Wilcoxon test $(\mathrm{p}<0.001)$ showed a significantly difference $(\Delta \%=-33.3 *)$.

In the animals of group A (3 weeks) the mean (46.8\%) and the median $(49.8 \%)$ of index stenosis showed no significant difference (Mann Whitney test $\mathrm{p}<0.001$ ) in comparison with the mean $(55.1 \%)$ and median $(52.4 \%)$ of the animals from group B (6 weeks).

The external and internal diameters in the cranial (point A) and caudal (point C) showed no differences in both observation periods of 3 and 6 weeks.

The mean and standard deviation $(\mathrm{cm})$ values of internal diameter point $\mathrm{C}$ (stenosis middle area) in the antero-posterior direction from animals of group $\mathrm{A}$ ( 3 weeks) on the $1^{\text {st }}$ day $(1.6 \pm 0.1)$ and $42^{\text {nd }}$ day $(1.2 \pm 0.4)$ showed a significantly $(\mathrm{p}<0.001)$ difference (Wilcoxon test $-\Delta \%=-25.4 *$ ). From the animals of group B ( 3 weeks) on the $1^{\text {st }}$ day $(1.6 \pm 0.2)$ and $42^{\text {nd }}$ day $(0.7 \pm 0.2)$ the Wilcoxon test showed no significantly $(\mathrm{p}<0.001)$ difference $(\Delta \%=-12.1)$

The mean and standard deviation $(\mathrm{cm})$ values of internal diameter point $\mathrm{C}$ (stenosis middle area) in the latero-lateral direction from animals of group $\mathrm{A}$ ( 3 weeks) on the $1^{\text {st }}$ day $(1.7 \pm 0.2)$ and $42^{\text {nd }}$ day $(1.2 \pm 0.4)$ showed a significantly $(\mathrm{p}<0.001)$ difference (Wilcoxon test $-\Delta \%=-64.3^{*}$ ). From animals of group $\mathrm{B}$ ( 3 weeks) on the $1^{\text {st }}$ day $(1.7 \pm 0.1)$ and $42^{\text {nd }}$ day $(0.7 \pm 0.1)$ the Wilcoxon test showed a significantly $(\mathrm{p}<0.001)$ difference $(\Delta \%=-51.0 *)$

\section{Discussion}

The treatment and management of congenital as well as post-traumatic trachea stenosis remain a challenge. ${ }^{16}$ Numerous surgical proceedings of tracheal replacement, including prostheses, autologous and heterologus tissues have been used, but none of them has properly replaced the injured trachea..$^{9,18}$ Moreover, there is no appropriate alloplastic material developed until the present moment and its possible use in reconstructive surgery of large segment trachea defects would bring about positive long-term experimental results. ${ }^{9,11,18}$

Various studies have reported conflicting results concerning alternative techniques and suture materials for tracheal anastomosis. ${ }^{17}$ In this way, a feasible and safe animal model of
TS would be useful to test the different surgical techniques or materials to the reconstruction of severe tracheal injury.

An ideal animal model for studying TS does not currently exist; ${ }^{11}$ several studies have used rats, rabbits, dogs, pigs or sheep as a wound healing model, ${ }^{17}$ most of them by promoting an acute injury on the tracheal tube followed by the specific tested tracheal reconstruction. In our understanding, the resection of variable shape and length of anterior trachea following by an immediate repair is not a reliable model to simulate the common clinical findings of TS. The models only attempted to diminish the tracheal patency. The model as proposed hereby, in addition to the patency impairment, was associated to the shrinking of the trachea and to the presence of important fibrous tissues mimeting actual and standard TS.

In spite of the extension, the provoked stricture at the $3^{\text {rd }}$ $(46.8 \%)$ or $6^{\text {th }}$ weeks $(50.1 \%)$ was higher than other reports in rats, ${ }^{18,19}$ rabbits, ${ }^{8,20,21}$ pigs, ${ }^{13,22}$ sheep ${ }^{5,9,10}$ or dogs. ${ }^{7,11,12,23}$ No death was recorded, although the weight loss was more significant among the animals that went through 6 weeks observation. All the animals remained healthy and no mechanical or pulmonary ventilation distress occurred in both periods of observation.

Authors related TS ranging from $22 \%$ to $82 \%$ in rabbits, ${ }^{20}$ $25 \%$ to $75 \%$ in pigs $^{13}$ and $30 \%$ to $60 \%$ in dogs. ${ }^{7}$ Our model promotes a stable and regular tracheal stricture in $3($ mean $=46.8 \%)$ or 6 weeks $($ mean $=55.1 \%)$. The external airway diameters measured at first day in comparison with $21^{\text {st }}(\Delta \%=-29.9 \%)$ or $42^{\text {nd }}$ day $(\Delta \%=-33.3 \%)$ showed that the initial stricture was significantly different after the healing process. As we hypothesized, the surgical defect after the healing time of 3 weeks, or even after 6 weeks, was stable and can be used as a more reliable model for TS than the simple acute defect on the tracheal wall.

The internal diameters measures were important in order to compare them to the anatomical structure of trachea. ${ }^{13,17,22}$ The antero-posterior diameter had a lesser percentual variation (3 weeks $/ \Delta \%=-25.4)(6$ weeks $/ \Delta \%=-12.1)$ than the latero-lateral diameter (3 weeks / $\Delta \%=-64.3)(6$ weeks $/ \Delta \%=-51.0)$, probably due to the fibrous tissue that retracted the soft posterior tracheal tissue, instead of the rigid composition of the tracheal ring that made it difficult for the latero-lateral diameter.

The model must be tested in another animal model, as for example in sheep, whose trachea is of comparable size to that of humans..$^{10}$ It is also necessary a complementary study to establish the relations ${ }^{17}$ between the extension/numbers of rings and the extension/grade of induced stenosis. Functional study must be performed to clarify the possible mechanism of wheeze generation $^{22}$ in this realistic tracheostenosis model.

\section{Conclusion}

The surgical proceeding was effective to promote a model of longitudinal and extensive tracheal stenosis.

\section{References}

1. Schweizer P. Berger S. Petersen M. Kirschner HJ. Schweizer M. Tracheal surgery in children. Eur J Pediatr Surg. 2005;15(4):236-42.

2. Schneider T, Storz K, Dienemann H, Hoffmann H. Management of iatrogenic tracheobronchial injuries: a retrospective analysis of 29 cases. Ann Thorac Surg. 2007;83(6):1960-4. 
3. George M, Lang F, Pasche P, Monnier P. Surgical management of laryngotracheal stenosis in adults. Eur Arch Otorhinolaryngol. 2005;262(8):609-15.

4. Mori N, Masuya D, Gotou M, Nakashima T, Liu D, Ishikawa S, Yamamoto Y, Huang C, Yokomise H. Kyobu Geka. 2007;60(10):899-902. 5. Behrend M, Klempnauer J. Influence of suture material and technique on end-to-end reconstruction in tracheal surgery: an experimental study in sheep. Eur Surg Res. 2001;33(3):210-6.

6. Elliott M, Roebuck D, Noctor C, McLaren C, Hartley B, Mok Q,Dunne C, Pigott N, Patel C, Patel A, Wallis C. The management of congenital tracheal stenosis. Int J Pediatr Otorhinolaryngol. 2003;67(Suppl 1):S183-92.

7. Abdelkafy WM, El Atriby MN, Iskandar NM, Mattox DE, Mansour KA.Slide tracheoplasty applied to acquired subglottic and upper tracheal stenosis: an experimental study in a canine model. Arch Otolaryngol Head Neck Surg. 2007;133(4):327-30.

8. Klin B, Weinberg M, Vinograd I, Sandbank J, Siman-Tov Y, Astachov L, Ayalon O, Rochkind S, Shahar A, Nevo Z. Experimental repair of tracheal defects using a new biodegradable membrane. J Laparoendosc Adv Surg Tech A. 2007;17(3):342-9.

9. Scierski W, Namyslowski G, Blazewicz S, Pilch J, Blazewicz M,Konieczna B. New composite implant for tracheal reconstructionpreliminary study. Otolaryngol Pol. 2004;58(4):765-70.

10. Schultz P, Vautier D, Charpiot A, Lavalle P, Debry C. Development of tracheal prostheses made of porous titanium: a study on sheep. Eur Arch Otorhinolaryngol. 2007;264(4):433-8.

11. Cibantos Filho JS, de Mello Filho FV, Campos AD, Ellinguer FV. Viability of a 12-ring complete tracheal segment transferred in the form of a compound flap: an experimental study in dogs. Laryngoscope. 2004;114(11):1949-52.

12. Suh SW; Kim J, Baek CH, Han J, Kim H. Replacement of a tracheal defect with autogenous mucosa lined tracheal prosthesis made from polypropylene mesh. ASAIO J. 2001;47(5):496-500.

13. Christoforidis D, Pezzetta E, Simon-Valla S, Lang F, Gebhardt S, Pasche $\mathrm{P}$, Ris HB. Repair of non-circumferential cervical trachea defects by three different latissimus dorsi flaps. Eur Surg Res. 2005;37(3):129-36.
14. Hisamatsu C, Maeda K, Tanaka H, Okita Y. Transplantation of the cryopreserved tracheal allograft in growing rabbits: effect of immunosuppressant. Pediatr Surg Int. 2006;22(11):881-5.

15. Kobayashi M, Fukuda A, Onozuka N, Kawagoe C, Wakayama F,Harada O. Design of a new technique using a free tracheal autologous graft for reconstruction of the cricoid cartilage and trachea. Surg Today. 2006;36(4):316-20.

16. Ruszymah BH, Chua K, Latif MA, Hussein FN, Saim AB. Formation of in vivo tissue engineered human hyaline cartilage in the shape of a trachea with internal support. Int $\mathrm{J}$ Pediatr Otorhinolaryngol. 2005;69(11):1489-95.

17. Loewen MS, Walner DL. Dimensions of rabbit subglottis and trachea. Lab Anim. 2001;35(3):253-6.

18. Liman ST, Kara CO, Bir F, Yildirim B, Topcu S, Sahin B. The effects of estradiol and progesterone on the synthesis of collagen in tracheal surgery. Int J Pediatr Otorhinolaryngol. 2005;69(10):1327-31.

19. Pata YS, Akbas Y, Unal M, Aydin O, Görür K, Ozcan C, Polat G Prevention of laryngotracheal stenosis with carnitine after tracheotomy: an experimental study on rats. Int J Pediatr Otorhinolaryngol. 2003;67(8):881-8.

20. Nakagishi Y, Morimoto Y, Fujita M, Ozeki Y, Maehara T, Kikuchi M. Rabbit model of airway stenosis induced by scraping of the tracheal mucosa. Laryngoscope. 2005;115(6):1087-92.

21. Zhang R, Liang C, Qin T, Li X, Liu J. Experimental reconstruction of extensive anterior defect of rabbit trachea with the use of free auricular cartilage. Hua Xi Yi Ke Da Xue Xue Bao. 2002;33(2):270-3.

22. Sera T, Satoh S, Horinouchi H, Kobayashi K, Tanishita K. Respiratory flow in a realistic tracheostenosis model. J Biomech Eng. 2003;125(4):461-71.

23. Olmos-Zúñiga JR, Santos-Cordero JA, Jasso-Victoria R, Sotres-Vega A, Gaxiola-Gaxiola MO, Mora-Fol JR, Franco-Oropeza JA, SantillanDoherty P. Effect of the hyaluronic acid on tracheal healing. A canine experimental model. Acta Otorrinolaringol Esp. 2004;55(2):81-7.

\section{Correspondence:}

Djalma José Fagundes

Rua Camé, 244/33

03121-020 São Paulo - SP Brazil

Phone: (55 11)2604-3186

Fax: (55 11)2604-3147

djfagundes.dcir@epm.br

Conflict of interest: none

Financial source: none

Received: May 29, 2008

Review: July 30, 2008

Accepted: August 27, 2008

\section{How to cite this article}

Vaidergorn J, Fagundes DJ, Machado AL, Ferreira RG, Juliano Y, Novo NF, Gomes PO. Model of extensive and severe tracheal stenosis in dogs. Acta Cir Bras. [serial on the Internet] 2008 Nov-Dec;23(6). Available from URL: http://www.scielo.br/acb 